\title{
New evidence for Cu-decorated binary-oxides mediating bacterial inactivation/mineralization in aerobic media
}

\section{S. Rtimi ${ }^{1}$, C. Pulgarin ${ }^{1}$, M. Bensimon ${ }^{3}$, J. Kiwi ${ }^{1 *}$}

${ }^{1}$ Ecole Polytechnique Fédérale de Lausanne, EPFL-SB-ISIC-GPAO, Station 6, CH1015, Lausanne, Switzerland.

2 Ecole Polytechnique Fédérale de Lausanne, EPFL-ENAC-IIEGR-CEL, Bat GC, Station 18, CH-1015, Lausanne, Switzerland.

Corresponding author: john.kiwi@epfl.ch

Number of words: 4175

Number of figures: 7

Number of Tables: 1 


\begin{abstract}
:
Binary oxide semiconductors $\mathrm{TiO}_{2}-\mathrm{ZrO}_{2}$ and $\mathrm{Cu}$ decorated $\mathrm{TiO}_{2}-\mathrm{ZrO}_{2}\left(\mathrm{TiO}_{2}-\mathrm{ZrO}_{2}-\mathrm{Cu}\right)$ uniform films were sputtered on polyester (PES). Under low intensity solar light these samples mediated the aerobic and anaerobic bacterial inactivation (CFU plate counting) and mineralization by generation of $\mathrm{CO}_{2}$. Bacterial inactivation and mineralization was possible only on $\mathrm{TiO}_{2}-\mathrm{ZrO}_{2}-\mathrm{Cu}$ under sunlight in aerobic conditions. Only bacterial inactivation was observed under anaerobic conditions. By the addition of appropriate scavengers, the highly oxidative radicals intervening in bacterial were identified. In addition, the hole generated $\mathrm{TiO}_{2}-\mathrm{ZrO}_{2} \mathrm{vb}\left(\mathrm{h}^{+}\right)$generated under light was determined to be the main species leading to bacterial inactivation. Inductively coupled plasma mass spectrometry (ICP-MS) revealed that during bacterial inactivation $\mathrm{TiO}_{2}{ }^{-}$ $\mathrm{ZrO}_{2}$ and $\mathrm{TiO}_{2}-\mathrm{ZrO}_{2}-\mathrm{Cu}$ PES films release $\mathrm{Zr}$ and $\mathrm{Ti}<1 \mathrm{ppb}$ and $\mathrm{Cu} \sim 4.6 \mathrm{ppb} / \mathrm{cm}^{2}$. This is far below the cytotoxicity limits allowed for mammalian cells and the values in the ppb range suggest a disinfection proceeding through an oligodynamic effect. By Fourier transform attenuated infrared spectroscopy (ATR-FTIR), the systematic shift of the predominating $v_{\mathrm{s}}\left(\mathrm{CH}_{2}\right)$ vibration-rotational of the cell wall outer layers was monitored providing a mechanistic reaction explanation within bacterial inactivation times. Repetitive catalyst cycling leading to bacterial disinfection points out to the stability of the binary-oxides selected in the present study.
\end{abstract}

Keywords: Cu/binary-oxides, oxidative radicals, aerobic/anaerobic media, $\mathrm{pH} /$ potential shift, ppb-ion leaching, FTIR shifts 


\section{Introduction}

Resistance of bacteria to antibiotics is a serious health problem leading to an increase in the hospital-acquired infections (HAl) [1-2]. Therefore, the development of innovative antibacterial surfaces presenting long-term operational lifetimes, biocompatibility and mechanical resistance as addressed in this study is warranted. $\mathrm{Cu}$ has been known for long time to have effective bactericide action [3]. More recently Cu-ions have been reported to be biocidal by binding to specific sites in the DNAphosphate destroying the DNA double helix or damaging the bacterial cell wall. In the latter case, the $\mathrm{Cu}$-ions enter into the cytoplasm causing membrane disruption [4-5]. Sol-gel commercial preparations are widely used at the present time to prepare Agthin disinfecting films on heat resistant substrates. But the thickness of these sol-gel deposited films is not reproducible, they are not mechanically stable, and they exhibit low adhesion and can be wiped off by a cloth or by hand contact [6]. Colloid deposition on substrates require temperatures of few hundred degrees for an adequate adherence to the substrate and this will not work on low thermal resistant substrates like PES used in this study

This study reports new findings for the bacterial inactivation by thin uniform films of $\mathrm{TiO}_{2}-\mathrm{ZrO}_{2}$ and $\mathrm{TiO}_{2}-\mathrm{ZrO}_{2}-\mathrm{Cu}$ films on PES following our first study on these materials [7]. These photocatalysts were reported recently by our group to be active in bacterial inactivation [7] and were reported before as catalysis and optical/electronic devices prepared by sol-gel methods and calcined on substrates resisting higher temperatures [8-9]. By inductively coupled plasma mass- spectrometry (ICP-MS) we will show that the $\mathrm{TiO}_{2}-\mathrm{ZrO}_{2}$ and $\mathrm{Cu}$ decorated $\mathrm{TiO}_{2}-\mathrm{ZrO}_{2}$ release of $\mathrm{Ti}, \mathrm{Zr}$ and $\mathrm{Cu}$ is far below amounts permitted by sanitary regulations [10-11]. This suggests that the $E$. coli disinfection occurs through an oligodynamic effect [14-15]. The present study reports new features for the selected photocatalysts activated by low intensity solar light leading to fast bacterial inactivation kinetics compared to other materials already reported [14-15]. The bacterial inactivation/ mineralization in aerobic media will be described in this study. Identification of the $\mathrm{OH}^{\circ}$-radical generated as a function of the bacterial inactivation time is reported and a rational for the bacterial inactivation time is presented consistent with the ATR-FTIR spectroscopic findings. 


\section{Experimental Section}

2.1 Preparation of binary oxides films by sputtering, quantitative analysis of the film content by $X$-ray fluorescence (XRF) and $\mathrm{CO}_{2}$ measurements

Thin $\mathrm{Ti}$ and $\mathrm{Zr}$ films were sputtered on PES by direct current magnetron sputtering (DCMS) at $200 \mathrm{~mA}$ and $300 \mathrm{~V}$ in a reactive oxygen atmosphere using a mixed target of $\mathrm{Ti}$ and $\mathrm{Zr}$ (50\%-50\%) obtained from K. Lesker, Hastings, UK. The substrate-to-target distance was $10 \mathrm{~cm}$ and the targets were 2 inches in diameter. $\mathrm{Cu}$ sputtering on the $\mathrm{TiO}_{2}-\mathrm{ZrO}_{2}$ layers was applied for times up to $10 \mathrm{~s}$. The $\mathrm{TiO}_{2}, \mathrm{ZrO}_{2}$ and $\mathrm{Cu}$-content in the samples were evaluated by X-ray fluorescence in a PANalytical PW 2400 unit as a function of the sputtering time. The PES used was Dacron, type 54 spun, plain weave ISO 105-F04 (EMPA) used for color fastness determinations. The nominal thickness calibration of the $\mathrm{TiO}_{2}-\mathrm{ZrO}_{2}$ films was carried out on Si-wafers with a profilometer (Alphastep500, TENCOR). $\mathrm{CO}_{2}$ was monitored using a micro-GC 3000 (Agilent Technologies) provided with a PoraPlot $\mathrm{U} 8 \mathrm{~m}$ column using He as carrier gas.

2.2 CFU counting, irradiation procedures and ICP-MS determination of the $\mathrm{Ti}, \mathrm{Zr}$ and Cu released during bacterial inactivation

Escherichia coli (E. coli K12 ATCC23716) on $2 \mathrm{~cm}$ by $2 \mathrm{~cm}$ sputtered samples were placed into a glass Petri dish and irradiated in the cavity reactor. $100 \mu \mathrm{L}$ culture aliquots with an initial concentration of $\sim 10^{6}$ colony forming units (CFU mL ${ }^{-1}$ ) in $\mathrm{NaCl} / \mathrm{KCl}(\mathrm{pH} 7)$ were placed on the samples. After pre-selected irradiation times, the samples were transferred into a sterile $2 \mathrm{~mL}$ Eppendorf tube containing $1 \mathrm{~mL}$ autoclaved $\mathrm{NaCl} / \mathrm{KCl}$ saline solution. This solution was subsequently mixed thoroughly using a Vortex for $3 \mathrm{~min}$. Serial dilutions were made in $\mathrm{NaCl} / \mathrm{KCl}$ solution. Samples of $100-\mu \mathrm{L}$ were pipetted onto a nutrient agar plate and then spread over the surface of the plate using standard plate method. Agar plates were incubated lid down, at $37^{\circ} \mathrm{C}$ for $24 \mathrm{~h}$ before counting. Three independent assays were done for each sputtered sample. The $\mathrm{TiO}_{2}-\mathrm{ZrO}_{2}$ films (with and without $\mathrm{Cu}$ ) were kept in a sterile oven at $60^{\circ} \mathrm{C}$ to avoid contamination prior to the bacterial test. The $100-\mu \mathrm{L}$ bacteria samples were then uniformly distributed on the samples. Irradiations by means of a low intensity Suntest solar simulator (Atlas Heraeus, GmbH Hananu, DE. A cut-off filter was inserted in the irradiating cavity to block the light below $310 \mathrm{~nm}$. Samples were irradiated in a glass Petri dishes provided with a lid to prevent evaporation in the Suntest irradiation cavity. The agar was purchased from Merck GmbH, Microbiology 
division $\mathrm{KGaA}$ under the catalogue $\mathrm{N}^{\circ}$ 1.05463.0500. The CFU statistical analysis was performed calculating the standard deviation values.

Determination by inductively coupled-plasma mass-spectrometry (ICP-MS) of $\mathrm{Ti}, \mathrm{Zr}$ and Cu-ions was carried out by way of a FinniganTM ICPS unit equipped with a double focusing reverse geometry mass spectrometer with an extremely low background signal and a high ion-transmission coefficient. The $\mathrm{TiO}_{2}, \mathrm{ZrO}_{2}$ and $\mathrm{Cu} / \mathrm{Cu}$ oxides and the washing solution were digested with nitric acid $69 \%\left(1: 1 \mathrm{HNO}_{3}+\mathrm{H}_{2} \mathrm{O}\right)$ to remove the organics in the solution and to guarantee that there were no remaining ions adhered to the flask wall. The samples droplets are introduced to the ICP-MS trough a peristaltic pump to the nebulizer chamber at $\sim 7700^{\circ} \mathrm{C}$ allowing the sample components evaporation and ionization. The $\mathrm{Ti}, \mathrm{Zr}$ and $\mathrm{Cu}$ found in the nebulizer droplets were subsequently quantified by mass spectrometry (MS). The results found during the recycling of both catalytic films are shown in Table 1.

\subsection{Monitoring the local $\mathrm{pH}$ and interfacial potential shifts during bacterial inactivation}

The local-pH and interfacial potential analysis was followed by means of a Jenco $6230 \mathrm{~N}(\mathrm{pH} / \mathrm{mV} /$ temperature meter) with a hand-held microprocessor in splash proof case with 3 points calibration. The device can be monitored via RS-232-C IBM compatible communication interface and BNC, pH/ORP connector with 8-pin DIN ATC connector.

\subsection{Infrared spectroscopy (ATR-FTIR) and irradiation procedures}

FTIR spectra were measured in a Portmann Instruments AG spectrophotometer equipped with a Specac attachment ( $45^{\circ}$ one pass diamond crystal). Spectra were taken by 256 scans with a resolution of $2 \mathrm{~cm}^{-1}$ in the range $900-4000 \mathrm{~cm}^{-1}$. The position of the IR peaks was found by the second derivative of the spectra after Fourier deconvolution. The samples were irradiated in the cavity of a Suntest solar light simulator from Heraeus AG, Hanau, DE.

\section{Results and discussion}

3.1 DRS of $\mathrm{TiO}_{2}-\mathrm{ZrO}_{2}$ and scavenging of the radicals generated by $\mathrm{TiO}_{2}-\mathrm{ZrO}_{2}$ and $\mathrm{TiO}_{2}-\mathrm{ZrO}_{2}-\mathrm{Cu}$ under light irradiation

Figure 1, traces 1-3) the diffuse reflectance spectra of $\mathrm{TiO}_{2}, \mathrm{ZrO}_{2}$ and $\mathrm{TiO}_{2}-\mathrm{ZrO}_{2}$ composites sputtered for 8 min on PES. It is readily seen in Figure that the $\mathrm{TiO}_{2}-\mathrm{ZrO}_{2}$ 
spectrum (Figure 1, trace 3) presents a different spectrum compared to the $\mathrm{TiO}_{2}$ and $\mathrm{ZrO}_{2}$. Networking in the binary oxide $\mathrm{TiO}_{2}-\mathrm{ZrO}_{2}$ has been cited as responsible for this effect, but a clear structure for this composite has not been reported yet [7-9]. Rtimi et al., have reported recently lower bacterial inactivation kinetics by $\mathrm{TiO}_{2}$ and $\mathrm{ZrO}_{2}$ each by itself when compared to the co-sputtered binary oxides [7]. The XRF determination of weight $\%$ of $\mathrm{TiO}_{2}$ and $\mathrm{ZrO}_{2}$ revealed $0.47 \mathrm{wt} \% / \mathrm{wt} \mathrm{PES}$ for each one on a sample of $\mathrm{TiO}_{2}-\mathrm{ZrO}_{2}$ sputtered for $8 \mathrm{~min}$. Sputtering $\mathrm{TiO}_{2}-\mathrm{ZrO}_{2}$ for $6 \mathrm{~min}$ led to lower concentrations (of $\mathrm{TiO}_{2}$ and $\mathrm{ZrO}_{2}$ ) revealed insufficient to induce a fast bacterial inactivation kinetics. Samples sputtered for $12 \mathrm{~min}$ showed also lower bacterial inactivation kinetics compared to $\mathrm{TiO}_{2}-\mathrm{ZrO}_{2}$ sputtered for $8 \mathrm{~min}$. this can be attributed to the charge transfer/transport limited by the size of the grains forming the thin layers without taking into account the variability of the inter-particles contact area. This aspect is not the focus of the present study and will not be investigated.

Figure $2 \mathrm{a}$, trace (1) shows the bacterial inactivation within $120 \mathrm{~min}$ by $\mathrm{TiO}_{2}-\mathrm{ZrO}_{2}(8$ min/10s) sputtered PES samples. To sort out the relative contribution of the intermediate radicals generated at the $\mathrm{TiO}_{2}-\mathrm{ZrO}_{2}$ surface under low intensity sunlight, scavengers of the oxidative radicals produced during the bacterial inactivation time were added. Figure $2 \mathrm{a}$, trace 1) shows the bacterial inactivation by $\mathrm{TiO}_{2}-\mathrm{ZrO}_{2}$ films. Next, Figure 2, trace 2) shows the effect of $2 \mathrm{mM}$ ethylene-diamine-tetraacetic acid disodium salt (EDTA-2Na, $2 \mathrm{mM}$ ) a well-known vb hole scavenger $\mathrm{TiO}_{2} \mathrm{vb}\left(\mathrm{h}^{+}\right)$[9]. Figure 2a, trace 3) shows the effect of the $\mathrm{OH}^{\circ}$ scavenger dimethyl-sulfoxide (DMSO $2 \mathrm{mM}$ ) and Figure $2 \mathrm{a}$, trace 4 ) shows the effect of addition of dismutase (SOD $2 \mathrm{mM}$ ) an $\mathrm{O}_{2}{ }^{\mathrm{O}-}$ / superoxide scavenger. Figure 2, trace 5) shows the negligible bacterial inhibition when PES alone was irradiated under Suntest simulated light. In the last case, the CFU/ml concentration decreased only marginally by $0.3 \times 10^{7}$ within 4 hours in the dark. Figure 2, trace 4) shows that SOD a strong $\left(\mathrm{O}_{2}^{-}\right)$quencher inhibited to a great extent the bacterial inactivation on the $\mathrm{TiO}_{2}-\mathrm{ZrO}_{2}$ film.

Figure $2 \mathrm{~b}$, trace (1) shows the bacterial inactivation on the $\mathrm{TiO}_{2}-\mathrm{ZrO}_{2}-\mathrm{Cu}$ films. Traces (2), (3) and (4) refer to the bacterial inactivation kinetics when the adding: (2) SOD an $\mathrm{O}_{2}^{-}$scavenger: (3) DMSO and $\mathrm{OH}^{\circ}$-scavenger and finally (4) EDTA-2Na a hole $\left(\mathrm{h}^{+}\right)$ scavenger. The overall scavenging of the radicals using a similar amount of scavenger solution led to a more quenching of the intermediate radicals compared to the results 
reported in Figure 2a. The vb hole $\left(\mathrm{h}^{+}\right)$scavenged by EDTA-2Na turned out to be the most effective species precluding bacterial inactivation.

The band-gaps found using Tauc's method [16] for $\mathrm{TiO}_{2}(3.04 \mathrm{eV})$ and for $\mathrm{ZrO}_{2}(2.96$ $\mathrm{eV})$ which were higher compared to the band-gaps of $\mathrm{TiO}_{2}-\mathrm{ZrO}_{2}(2.47 \mathrm{eV})$ and $\mathrm{TiO}_{2}-$ $\mathrm{ZrO}_{2}-\mathrm{Cu}(2.25 \mathrm{eV})$. Therefore, a larger amount of the visible photons will be absorbed by $\mathrm{TiO}_{2}-\mathrm{ZrO}_{2}$ from the solar simulated light compared to either of the two oxides by themselves.

$\mathrm{TiO}_{2}-\mathrm{ZrO}_{2}-\mathrm{Cu}$ was shown in Figure $2 \mathrm{~b}$, trace 1) to accelerate drastically the bacterial inactivation kinetics compared to $\mathrm{TiO}_{2}-\mathrm{ZrO}_{2}$ shown in Figure 2a, trace 1). This may be ascribed to the narrower band of $\mathrm{TiO}_{2}-\mathrm{ZrO}_{2}-\mathrm{Cu}$. $\mathrm{Cu}$ makes narrower the $\mathrm{TiO}_{2}-\mathrm{ZrO}_{2}$ band-gap by a mechanism that has not been reported or explained yet due to the extremely low quantities of $\mathrm{Cu}$ present in the $\mathrm{TiO}_{2}-\mathrm{ZrO}_{2}-\mathrm{Cu}$ sample as described before. No doping by $\mathrm{Cu}$ can be claimed for the $\mathrm{Cu}$ added to $\mathrm{TiO}_{2}-\mathrm{ZrO}_{2}$ since the $\mathrm{Cu}$ amount sputtered is too small to induce a doping effect and for the same reason no evidence in the XRD-spectrogram was found for the Cu present in ppb amounts.

3.2. Evidence for bacterial mineralization under light irradiation in aerobic but not in anaerobic media.

Figure 3a presents the $\mathrm{CO}_{2}$ generation during bacterial inactivation photocatalyzed $\mathrm{TiO}_{2}, \mathrm{ZrO}_{2}$ in trace (1-2) and only slightly higher for the case of $\mathrm{TiO}_{2}-\mathrm{ZrO}_{2}$ films in trace (3) in aerobic media. Figure 3b, trace 1) presents present a clear evidence for the $\mathrm{CO}_{2}$ evolution under Suntest light irradiation. Therefore, E. coli mineralizes on $\mathrm{TiO}_{2}-\mathrm{ZrO}_{2}-$ $\mathrm{Cu}$ film in aerobic media. Figure 3b, traces (2-4) show that absence of $\mathrm{O}_{2}$ (air) under dark reaction conditions did not lead to bacteria mineralization. These results will be related below in section 3.3 to the experiments describing the local $\mathrm{pH}$ and surface potential changes during bacterial inactivation in the dark and under light.

\subsection{Local $\mathrm{pH}$-changes and surface potential evolution in the dark and under light}

Figure $4 \mathrm{a}$ presents the local $\mathrm{pH}$-shift at the $\mathrm{TiO}_{2}-\mathrm{ZrO}_{2}-\mathrm{Cu} / \mathrm{PES}$ interface in the dark within the bacterial inactivation time. $\mathrm{A} \mathrm{pH}$-shift between 7.0 and $\mathrm{pH} 6.6$ was observed within $2400 \mathrm{~s}$ or $45 \mathrm{~min}$. This is equivalent to a fourfold increase in the concentrations of $\mathrm{H}^{+}$. This $\mathrm{pH}$ change is due to short chain carboxylic acids (branched or not) generated in solution during the bacterial inactivation presenting with $\mathrm{pK}_{\mathrm{a}}$ values 
around 3 [5]. After 2400s the $\mathrm{pH}$ values in Figure 4a increase again up to $\mathrm{pH} \sim 6.7$ due to the elimination of short carboxylic acids through mineralization of the Cintermediates to $\mathrm{CO}_{2}$. This is the final step in the bacterial mineralization by $\mathrm{TiO}_{2}$ photocatalysis chain as reported for many organic compounds and dyes [5,17]. Figure 4a shows a pH-recovery step in the dark showing smaller amplitude between pH's 6.6 and 7.6. This $\mathrm{pH}$ recovery in the dark does not lead to $\mathrm{CO}_{2}$ mineralization as sown in Figure $3 \mathrm{a}$, trace $\mathrm{c}$ ). The $\mathrm{CO}_{2}$ generation observed under light in aerobic media involves a photo-Kolbe $\mathrm{CO}_{2}$ elimination reaction as shown below (1)[18].

$$
\mathrm{RCOO}-+\mathrm{TiO}_{2}-\mathrm{ZrO}_{2}-\mathrm{Cu} / \mathrm{PES}+\mathrm{hv} \rightarrow \mathrm{R}+\mathrm{CO}_{2}
$$

Figure $4 \mathrm{~b}$ shows a significant steeper $\mathrm{pH}$-decrease during the time of bacterial inactivation followed by a steep recovery to the initial $\mathrm{pH}$. ]. A much larger $\mathrm{pH}$ change is induced by $\mathrm{TiO}_{2}-\mathrm{ZrO}_{2}-\mathrm{Cu} / \mathrm{PES}$ under light irradiation and this seems to be a necessary condition to generate $\mathrm{CO}_{2}$. This observation is in line with the significant elimination of $\mathrm{CO}_{2}$ through a photo-Kolbe reaction reported previously in Figure $3 \mathrm{~b}$, trace 1 [18-19].

The interface potential on the $\mathrm{TiO}_{2}-\mathrm{ZrO}_{2}-\mathrm{Cu}$ PES film decreases during dark bacterial oxidation as shown in Figure $4 \mathrm{a}$, due to the increase permeability leading to the destruction of the $E$. coli bilayer cell wall during bacterial inactivation. The increase in cell wall permeability leads to loss of the barrier function to control exchange of ions [20-21].

The results reported in Figure $4 \mathrm{a}$ and Figure $4 \mathrm{~b}$ have shown a pH shift to more acidic values within the bacterial inactivation period. This observation can be related to Figures $2 \mathrm{a}$ and $2 \mathrm{~b}$ showing the bacterial inactivation in aerobic conditions for $\mathrm{TiO}_{2}-$ $\mathrm{ZrO}_{2}$ and $\mathrm{TiO}_{2}-\mathrm{ZrO}_{2}-\mathrm{Cu}$ PES films. The generation of $\mathrm{OH}^{\circ}$-radicals, $\mathrm{HO}_{2}{ }^{\circ} / \mathrm{O}_{2}{ }^{-}$species and $\mathrm{TiO}_{2}-\mathrm{ZrO}_{2} \mathrm{vb}(\mathrm{h}+)$ holes under band-gap irradiation was shown in Figures $2 \mathrm{a} / 2 \mathrm{~b}$ and bacterial inactivation mechanism consistent with the $\mathrm{pH}$-shift to more acidic values is suggested below in reactions (1-6) involving an unstable bacterial cationic species

$$
\begin{gathered}
\text { Bacteria }+\left[\mathrm{PES}-\mathrm{TiO}_{2}-\mathrm{ZrO}_{2}\right]+\text { light } \rightarrow\left[\mathrm{PES}-\mathrm{TiO}_{2}-\mathrm{ZrO}_{2}{ }^{*}\right] \text { Bacteria } \rightarrow \\
\text { Bacteria }{ }^{+}+\text {PES- }\left(\mathrm{TiO}_{2}-\mathrm{ZrO}_{2}\right) \text { cbe- } \\
\text { PES- }\left(\mathrm{TiO}_{2}-\mathrm{ZrO}_{2}\right) \text { cbe- }+\mathrm{O}_{2}+\mathrm{H}^{+} \rightarrow \mathrm{HO}_{2}{ }^{*} \quad \mathrm{E}_{0}-0.05 \mathrm{NHE} \text { [23] }
\end{gathered}
$$




$$
\begin{aligned}
& \text { PES- }\left(\mathrm{TiO}_{2}-\mathrm{ZrO}_{2}\right) \text { cbe- }+\mathrm{O}_{2 \text { ads }} \rightarrow \mathrm{O}_{2}{ }^{--} \text {ads } \mathrm{E}_{0}-0.16 \mathrm{NHE} \text { [23] } \\
& \mathrm{PES}-\left(\mathrm{TiO}_{2}-\mathrm{ZrO}_{2}\right) \mathrm{vbh}^{+}+\mathrm{OH}_{\text {ads }}^{-} \rightarrow \mathrm{OH} \bullet \quad \mathrm{E}_{0}-1.90 \mathrm{NHE} \text { [3] } \\
& \text { PES- }\left(\mathrm{TiO}_{2}-\mathrm{ZrO}_{2}\right) \mathrm{vbh}^{+}+\mathrm{H}_{2} \mathrm{O}_{\text {ads }} \rightarrow \mathrm{OH}^{\cdot} \text { ads }+\mathrm{H}^{+} \\
& \mathrm{O}_{2}^{\cdot-}+\mathrm{H}^{+} \Leftrightarrow \mathrm{HO}_{2}^{\cdot} \quad \mathrm{pK}_{\mathrm{a}} 4.8
\end{aligned}
$$

In reaction (2) the $\mathrm{HO}_{2}$ radical is stable at $\mathrm{pH}<4.8$, above this $\mathrm{pH}$ more than $50 \%$ is present in the form of $\mathrm{O}_{2}^{0^{-}}$as noted in reaction (6).

3.4 Effect of the light dose on to E. coli disinfection and repetitive bacterial inactivation by $\mathrm{TiO}_{2}-\mathrm{ZrO}_{2}-\mathrm{Cu}$ PES films. Mechanistic considerations.

Figure 5 shows the effect the light intensity applied to induce the bacterial inactivation mediated by $\mathrm{TiO}_{2}-\mathrm{ZrO}_{2}-\mathrm{Cu}$ and $\mathrm{ZrO}_{2}-\mathrm{TiO}_{2}$ films. Semiconductors like $\mathrm{TiO}_{2}$ and $\mathrm{ZrO}_{2}$ are affected by the amount of incident light dose, but it is not known to what degree Cu-intra-gap states are affected by the light dose [15]. Figure 5, traces 1), 2) show similar bacterial degradation at doses of $50 \mathrm{~mW} / \mathrm{cm}^{2}$ and $70 \mathrm{~mW} / \mathrm{cm}^{2}$. This suggests a saturation effect by the bacterial culture for the incident photons. Figure 5, trace 3) shows that when a lower intensity was applied, the kinetics becomes slower due to a lowers number of the induction of a lower number photo-induced surface charge carriers. The effect on the bacterial inactivation of the $\mathrm{Cu}$ is shown by comparing the runs with $\mathrm{TiO}_{2}-\mathrm{ZrO}_{2}-\mathrm{Cu}$ compared to the runs with $\mathrm{TiO}_{2}-\mathrm{ZrO}_{2}$ in Figure 5, trace 4). Addition of $\mathrm{Cu}$ in ppb amounts on $\mathrm{TiO}_{2}-\mathrm{ZrO}_{2}$ accelerated the bacterial inactivation. $\mathrm{Cu}$ intra-gap states/enhanced electron transfer or Cu-positive-ions have been reported interact by electrostatic attraction with bacteria. Only a low amount of $\mathrm{Cu}$ has been induce a high bacterial toxicity [12-13,22-23]. Last but not least, Figure 6a and Figure $6 \mathrm{~b}$ show the stable repetitive performance of the $\mathrm{TiO}_{2}-\mathrm{ZrO}_{2}-\mathrm{Cu}$ films. Figure $6 \mathrm{a}$ shows the bacterial inactivation induced by the $\mathrm{ZrO}_{2}-\mathrm{TiO}_{2}$ recycling up to the $5^{\text {th }}$ cycle. And Figure $6 \mathrm{~b}$ present similar runs mediated by $\mathrm{ZrO}_{2}-\mathrm{TiO}_{2}-\mathrm{Cu}$ films. No loss in activity was observed for either $\mathrm{ZrO}_{2}-\mathrm{TiO}_{2}$ or $\mathrm{ZrO}_{2}-\mathrm{TiO}_{2}-\mathrm{Cu}$ samples during the sample recycling. After each cycle the sample was thoroughly washed after run. These results show the potential for the application of binary-oxides decorated with $\mathrm{Cu}$ or not in disinfection processes.

\subsection{FTIR spectroscopic changes observed within the time of bacterial inactivation}


FTIR spectroscopy was used to monitor the shift in the $-\mathrm{CH}_{2}$ symmetric stretching vibration peak photo-induced by the $\mathrm{TiO}_{2}-\mathrm{ZrO}_{2}$ and $\mathrm{TiO}_{2}-\mathrm{ZrO}_{2}-\mathrm{Cu}$ samples between2800-2900 $\mathrm{cm}^{-1}$. The FTIR-signals allowed the detection of the IR-spectral shifts and concomitantly the reduction of amplitude during bacterial inactivation. Figure 7 a shows the discontinuous IR-peak shift for methylene $v_{s}\left(-\mathrm{CH}_{2}\right)$ from $2864 \mathrm{~cm}^{-1}$ at time zero up to $2858 \mathrm{~cm}^{-1}$ within $120 \mathrm{~min}$, the time required for complete bacterial inactivation. Figure $7 \mathrm{~b}$ presents the corresponding IR-shifts mediated by a $\mathrm{TiO}_{2}-\mathrm{ZrO}_{2}-$ Cu showing a similar trend during an accelerated bacterial inactivation occurring within 45 minutes. The IR treatment of the data has been already reported, and therefore will not be addressed in detail in the present study [24-25]. The shift peaks reflect an increasing $\mathrm{C}-\mathrm{C}$ bond distance increasing with irradiation time introducing disorder and polarization in the outer lipo-polysaccharide layers (LPS) of E. coli. This increase stretching leads to a more fluidity in the systems until the interbond scission sets in after $120 \mathrm{~min}$ for $\mathrm{TiO}_{2}-\mathrm{ZrO}_{2}$ and after $45 \mathrm{~min}$ for $\mathrm{TiO}_{2}-\mathrm{ZrO}_{2}-\mathrm{Cu}$. These times are in agreement with the bacterial inactivation reported in Figures $2 a / 2 b$ for both photocatalysts.

\section{Conclusions}

This study presents new evidence for different features associated with the bacterial inactivation / mineralization on $\mathrm{TiO}_{2}-\mathrm{ZrO}_{2}$ and $\mathrm{TiO}_{2}-\mathrm{ZrO}_{2}-\mathrm{Cu}$ films. E. coli inactivation on $\mathrm{TiO}_{2}-\mathrm{ZrO}_{2}$ and $\mathrm{TiO}_{2}-\mathrm{ZrO}_{2}-\mathrm{Cu}$ released $\mathrm{ppb}$ quantities of $\mathrm{Ti}, \mathrm{Zr}$ and $\mathrm{Cu}$. These quantities were below the toxicity limit set by sanitary regulations. This suggests disinfection through an oligodynamic effect. This study shows the effect of $\mathrm{Cu}$ on $\mathrm{TiO}_{2-}$ $\mathrm{ZrO}_{2}$. The role of the $\mathrm{Cu}$ on the mechanism of bacterial inactivation is up to now a controversial matter and more work is necessary to clarify this issue. The shifts in local-pH/interface potential provide insight into the intermediates produced on the photocatalyst surface in the dark and under light. Disinfection in the dark only induced small changes in the $\mathrm{pH} /$ potential within the period of bacterial inactivation compared to light activated reactions leading to bacterial mineralization in aerobic conditions.

\section{Acknowledgments}

We thank the EPFL and Swiss National Science Foundation (SNF) Project (200021143283/1) for financial support. We also thank the COST Action MP 1106 for discussions during the course of this study. 
Table 1. Atomic release during $\mathrm{PES}-\mathrm{TiO}_{2}-\mathrm{ZrO}_{2}$ and $\mathrm{PES}-\mathrm{TiO}_{2}-\mathrm{ZrO}_{2} / \mathrm{Cu}$ recycling leading to bacterial inactivation detected by inductively coupled plasma mass spectrometry (ICP-MS).

\begin{tabular}{|l|l|ccc|}
\hline \multicolumn{2}{|c|}{} & $\mathrm{Ti}(\mathrm{ppb})$ & $\mathrm{Zr}(\mathrm{ppb})$ & $\mathrm{Cu}(\mathrm{ppb})$ \\
\hline \multirow{2}{*}{$\mathrm{TiO}_{2}-\mathrm{ZrO}_{2} / \mathrm{Cu}$} & Cycle 1 & $<1$ & 0.8 & 13.6 \\
& Cycle 3 & $<1$ & 0.2 & 5.9 \\
& Cycle 5 & $<1$ & 0.1 & 4.6 \\
\hline \multirow{2}{*}{$\mathrm{TiO}_{2}-\mathrm{ZrO}_{2}$} & Cycle 1 & $<1$ & $<1$ & -- \\
& Cycle 3 & $<1$ & $<1$ & -- \\
& Cycle 5 & $<1$ & $<1$ & -- \\
\hline
\end{tabular}




\section{References}

[1] S. Dancer, J. Hosp. Infect., 2009, 73, 378-386.

[2] I. Kramer, I. Schwebke, G. Kampf, G. BMC Infect. Diseases, 2006, 6,137-146.

[3] H. Foster, I, Ditta, S. Varghese, A. Steele, A. Appl. Microb. \& Biotech, 2012, 90, 1847-1868.

[4] Y. Ohsumi, K. Kitamoto, Y. Anraku, J. Bacteriol. 1988, 170, 2676-2682.

[5] A. Fujishima, X. Zhang, D. Tryck, Surf. Sci. Repts. 2008, 63, 515-582.

[6] L. Zhang, R. Dillert, D. Bahnemann, M. Vormoor, En. \& Environ. Sci. 2012, 5, 57491-7507.

[7] S. Rtimi, C. Pulgarin, R. Sanjines,V. Nadtochenko, J-C. Lavanchy, J. Kiwi, App/ Mater. \& Interf, 2015, 7, 12832-12839 (and references therein).

[8] T. Busko, O. Dmytrenko, M. Kulish, Y. Prylutskyy, S. Shokhovets, G. Gobsch, V. Vityuk, A. Eremenko, V. Tkach, Mat. Wiss. u. Werkstofftech. 2013, 44, 119-122.

[9] Ch. Kim, H. Jeong, Bull. Korean Chem. Soc. 2000, 28, 2333-2336.

[10] E. Rentz, J. of Nutritional and Environ. Medicine, 2003, 13, 109-118.

[11] H. J. Jeng, J. Swanson, J. Environ. Sci. \& Health, Part A, Toxic Hazard. Subst. \& Environ. Eng, 2006, 4, 2699-2711.

[12] W. K. Nägeli, Neue Denkschr. Allgeein. Schweiz. Gesellsch. Ges. Naturweiss. 1893, Bd XXXIII Abt 1. English archive: Nägeli, Denkschr. Allgemein. Naturfors Ges, 1983, 33, 174-182.

[13] B. Stobie, B. Duffy, D. Mccormack, J. Colreavy, M. Hidalgo, P. Mchale, and S. Hinder, Biomaterials 2008, 29(8), 963-69.

[14] S. Banerjee, S. Pillai, P. Falaras, K. O'Shea. J-A Byrne, D. Dionysiou, J. Phys. Chem. Letts., 2014, 5, 2543-2552.

[15] V. Etacheri, C. Di Valentin, J. Schneider, D. Bahnemann, S. C. Pillai, J. Photochem. Photobiol. C., 2015, 25, 1-29.

[16] J. Tauc, Mater. Res. Bulletin, 1968, 3, 37-46.

[17] A. Houas, H. Lachheb, M. Ksibi, E. Elaloui, C. Guillard, J-M Herrmann, Appl. Cat. B. 2001, 31, 145-157.

[18] A. Kraeutler, A. Bard, J. Am. Chem. Soc. 1978, 100, 239-2244.

[19] S. Sato, J. Phys. Chem, 1983, 87, 3531-3537.

[20] Z. Lu, Z.; L. Zhou, Z. Zhang, W. Shi, Z. Xie, D. Pang, P. Shen, Langmuir 2003,19, 8765-8768. 
[21] S. Maheshwari, K. Singh, U. Minchita, R. Balakrishna, J. Photochem. Photobiol A, 2012, 88, 414-422.

[22] J. Schneider, M. Matsuoka, M. Takeuchi, J. Zhang, Y. Horiuchi, M. Anpo, D. Bahnemann, Chem. Revs. 2014, 114, 9919-9986.

[23] D.W. Synnott, M. K Seery, S. J Hinder, G. Michlits and S. C. Pillai, Appl. Cat. B, 2013, 130-131, 106-111.

[24] S. Rtimi, R. Sanjines, M. Andrzejczuk, C. Pulgarin, A. Kulik, J. Kiwi, Surf. Coat. Technol. 2014, 254, 333-343

[25] S. Rtimi, C. Pulgarin, R. Sanjines, J. Kiwi, RSC-adv. 2013, 3, 16345-16348 


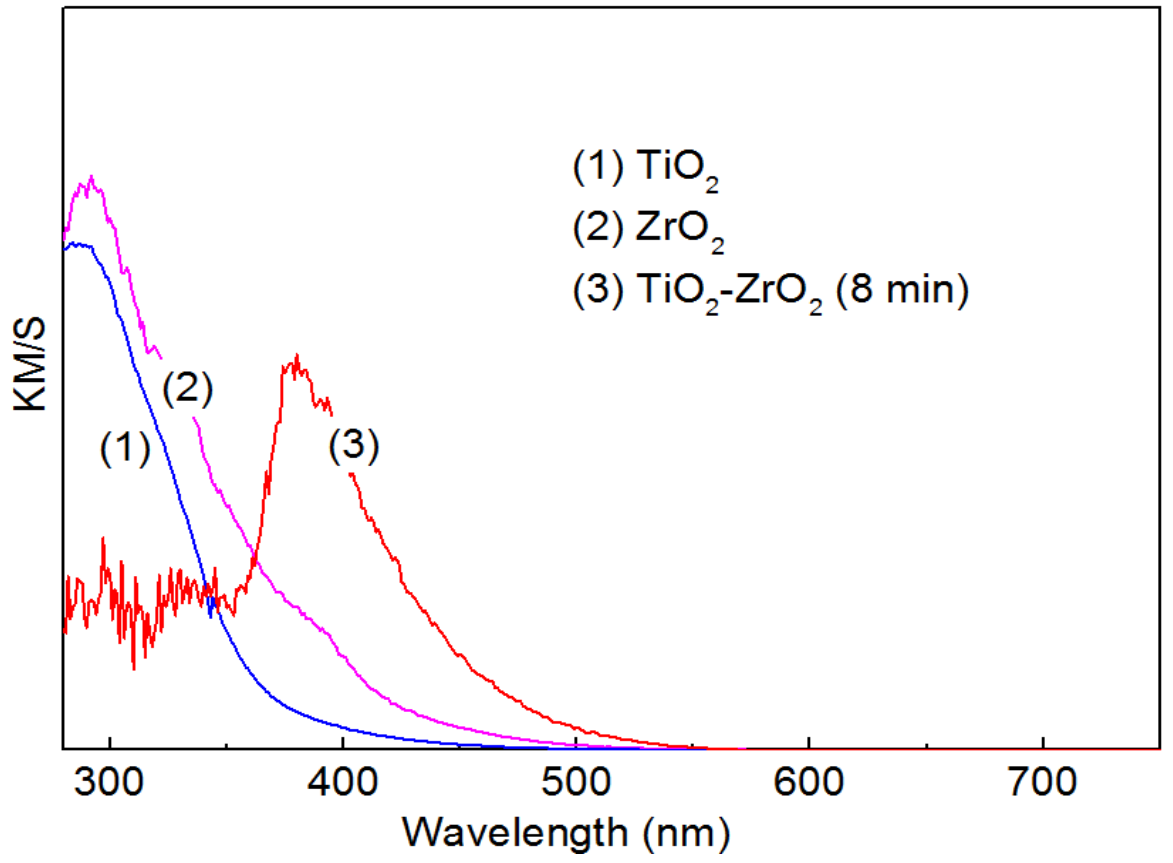

Figure 1. Diffuse reflectance spectroscopy of (1) $\mathrm{TiO}_{2}$, (2) $\mathrm{ZrO}_{2}$ and (3) $\mathrm{TiO}_{2}-\mathrm{ZrO}_{2}$ sputtered for $8 \mathrm{~min}$. 

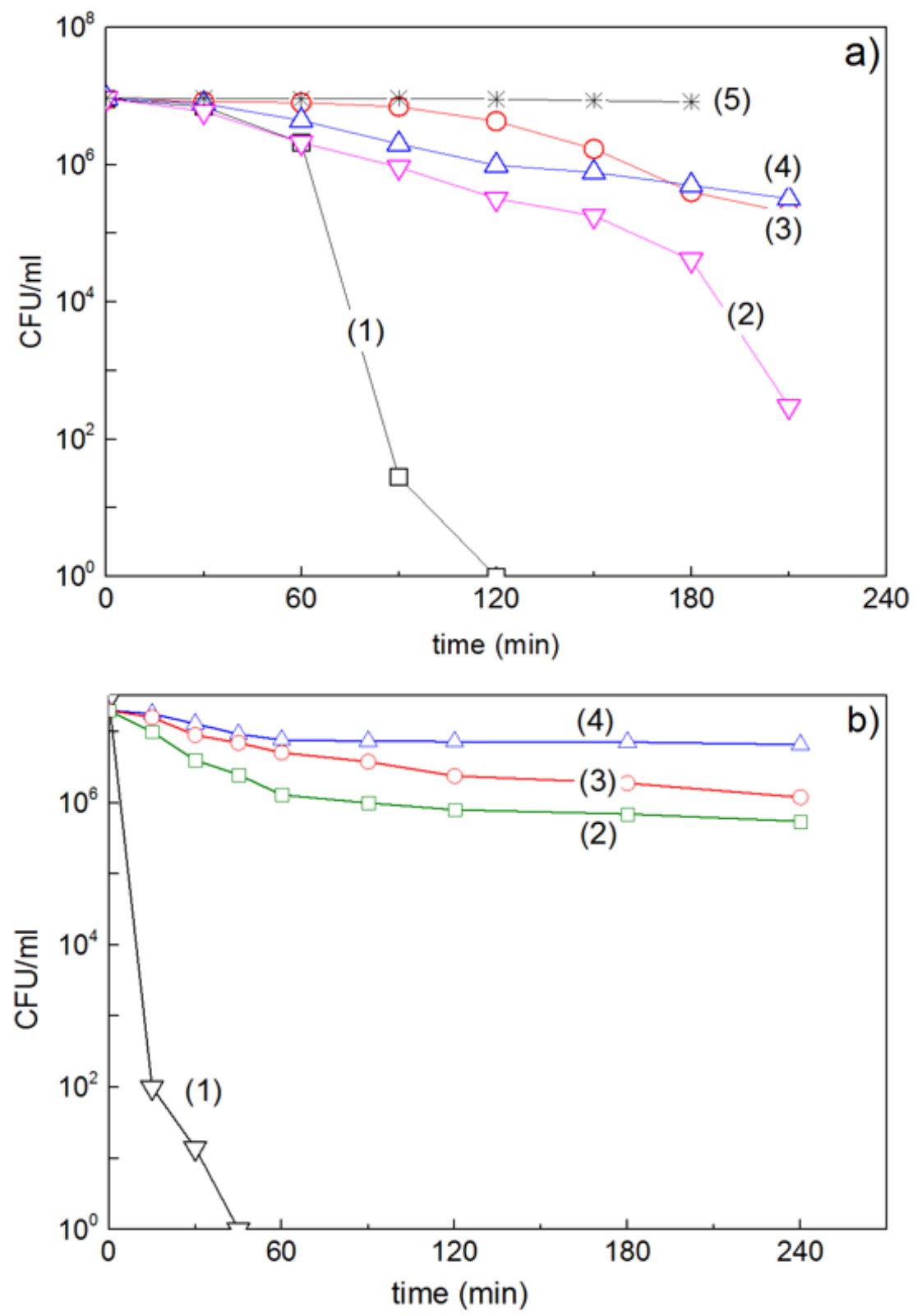

Figure 2a. Trace (1) E. coli inactivation on $\mathrm{TiO}_{2}-\mathrm{ZrO}_{2} \mathrm{PES}$ sputtered for 8 min under low intensity solar simulated light irradiation $\left(50 \mathrm{~mW} / \mathrm{cm}^{2}\right)$; trace (2) E. coli monitored as in trace (1) but adding $2 \mathrm{mM}$ EDTA-2Na; trace (3) run as in trace (1) but adding $2 \mathrm{mM}$ DMSO and finally trace (4) run as in trace (1) adding $2 \mathrm{mM} \mathrm{SOD}$ and finally trace (5) PES alone under solar simulated light irradiation $\left(50 \mathrm{~mW} / \mathrm{cm}^{2}\right)$.

Figure $\mathbf{2 b}$. $E$. coli inactivation under low intensity solar simulated light irradiation (50 $\mathrm{mW} / \mathrm{cm}^{2}$ ) on: (1) $\mathrm{TiO}_{2}-\mathrm{ZrO}_{2} / \mathrm{Cu}$ PES sputtered for (8 $\mathrm{min} / 10 \mathrm{~s}$ ); (2) $\mathrm{TiO}_{2}-\mathrm{ZrO}_{2} / \mathrm{Cu}$ (8 $\mathrm{min} / 10 \mathrm{~s})+2 \mathrm{mM} \mathrm{SOD} \mathrm{(3)} \mathrm{TiO}_{2}-\mathrm{ZrO}_{2} / \mathrm{Cu}(8 \mathrm{~min} / 10 \mathrm{~s})+2 \mathrm{mM}$ DMSO and (4) $\mathrm{TiO}_{2^{-}}$ $\mathrm{ZrO}_{2} / \mathrm{Cu}(8 \mathrm{~min} / 10 \mathrm{~s})+2 \mathrm{mM}$ EDTA-2Na. Light source: solar simulated light irradiation $\left(50 \mathrm{~mW} / \mathrm{cm}^{2}\right)$. 

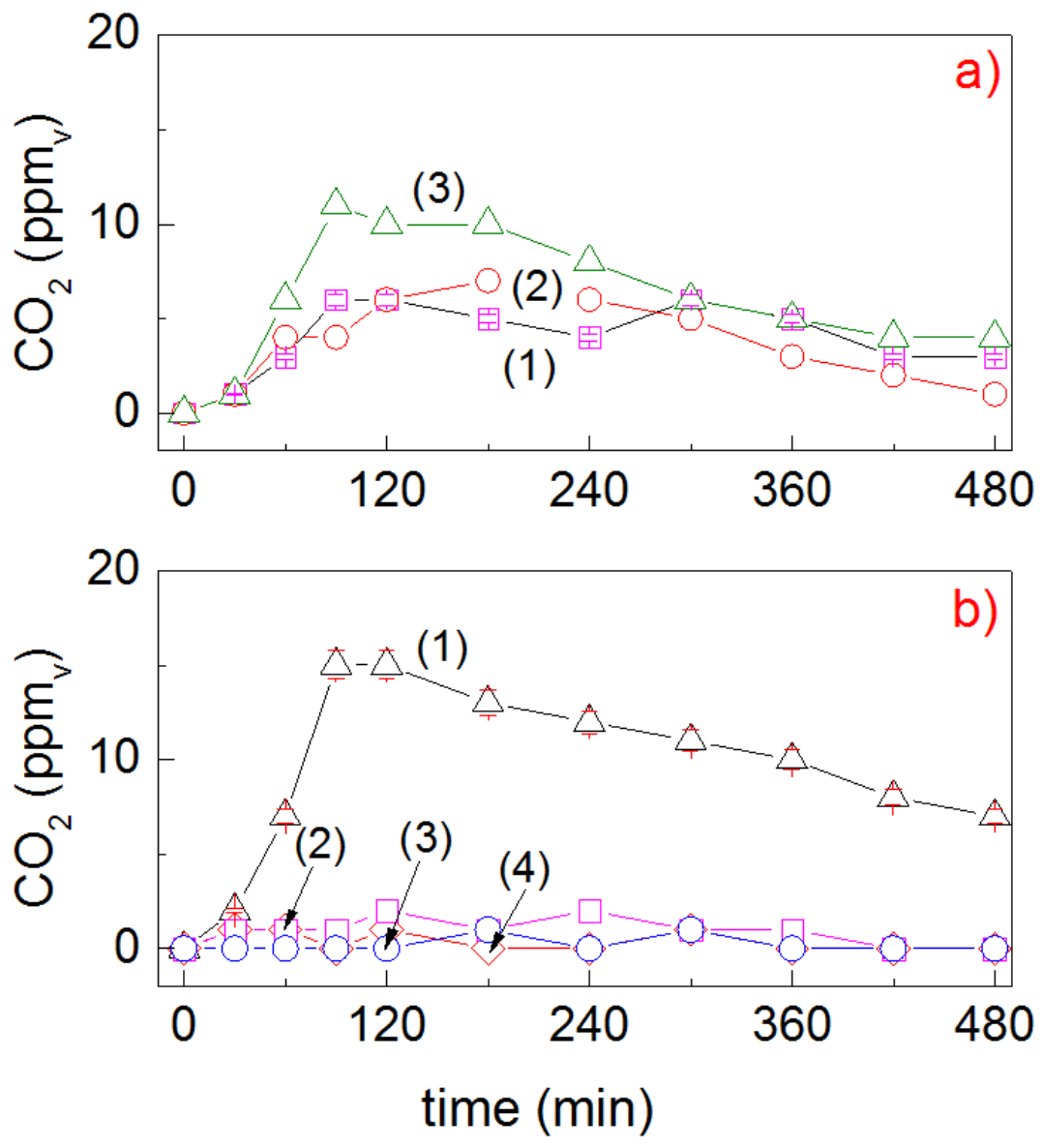

Figure 3a. $\mathrm{CO}_{2}$ production during bacterial inactivation by the films (1) $\mathrm{TiO}_{2} / \mathrm{PES}$ sputtered for $8 \mathrm{~min}$, (2) $\mathrm{ZrO}_{2} / \mathrm{PES}$ sputtered for $8 \mathrm{~min}$ and (3) $\mathrm{TiO}_{2}-\mathrm{ZrO}_{2} / \mathrm{PES}$ sputtered for $8 \mathrm{~min}$. Light source: solar simulated light irradiation $\left(50 \mathrm{~mW} / \mathrm{cm}^{2}\right)$.

Figure 3b. $\mathrm{CO}_{2}$ production during bacterial inactivation by the films: (1) $\mathrm{TiO}_{2}-$ $\mathrm{ZrO}_{2} / \mathrm{Cu} / \mathrm{PES}$ sputtered for $8 \mathrm{~min} / 10 \mathrm{~s}$ under aerobic conditions / light irradiation, (2) $\mathrm{TiO}_{2}-\mathrm{ZrO}_{2} / \mathrm{Cu} / \mathrm{PES}$ sputtered for $8 \mathrm{~min} / 10$ sunder anaerobic conditions / light irradiation, (3) $\mathrm{TiO}_{2}-\mathrm{ZrO}_{2} / \mathrm{Cu} / \mathrm{PES}$ sputtered for $8 \mathrm{~min} / 10 \mathrm{~s}$ under aerobic conditions $/$ in the dark and (4) $\mathrm{TiO}_{2}-\mathrm{ZrO}_{2} / \mathrm{Cu} / \mathrm{PES}$ sputtered for $8 \mathrm{~min} / 10 \mathrm{~s}$ under anaerobic conditions in the dark. 

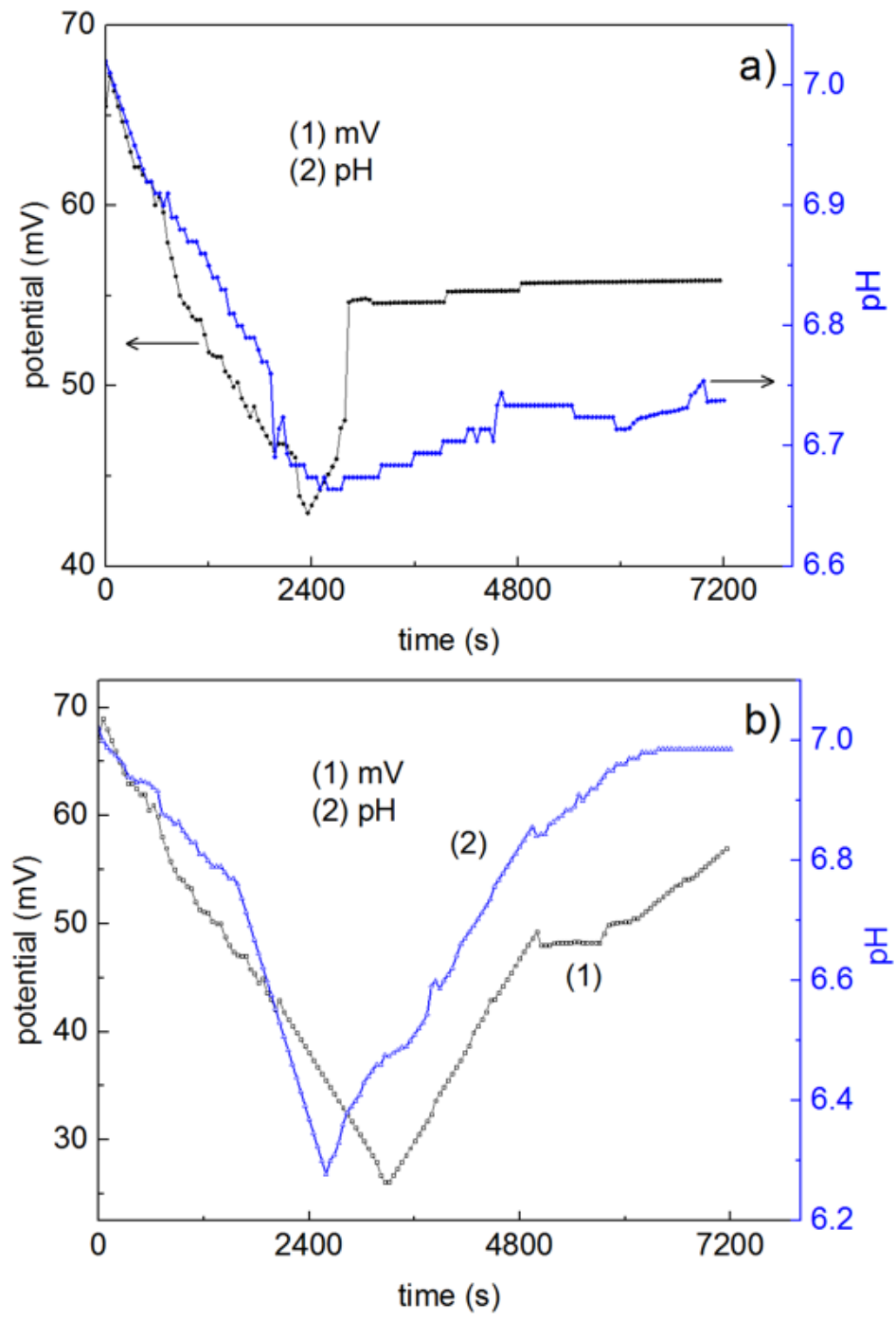

Figure 4a. Interfacial potential and local-pH shifts of the bacterial culture contacted with $\mathrm{TiO}_{2}-\mathrm{ZrO}_{2} / \mathrm{Cu}$ in the dark within the bacterial inactivation time.

Figure $4 \mathrm{~b}$. Interfacial potential and local $\mathrm{pH}$ shifts of the bacterial culture contacted with $\mathrm{TiO}_{2}-\mathrm{ZrO}_{2} / \mathrm{Cu}$ under light within the bacterial inactivation time. Suntest simulated light irradiation $\left(50 \mathrm{~mW} / \mathrm{cm}^{2}\right)$. 


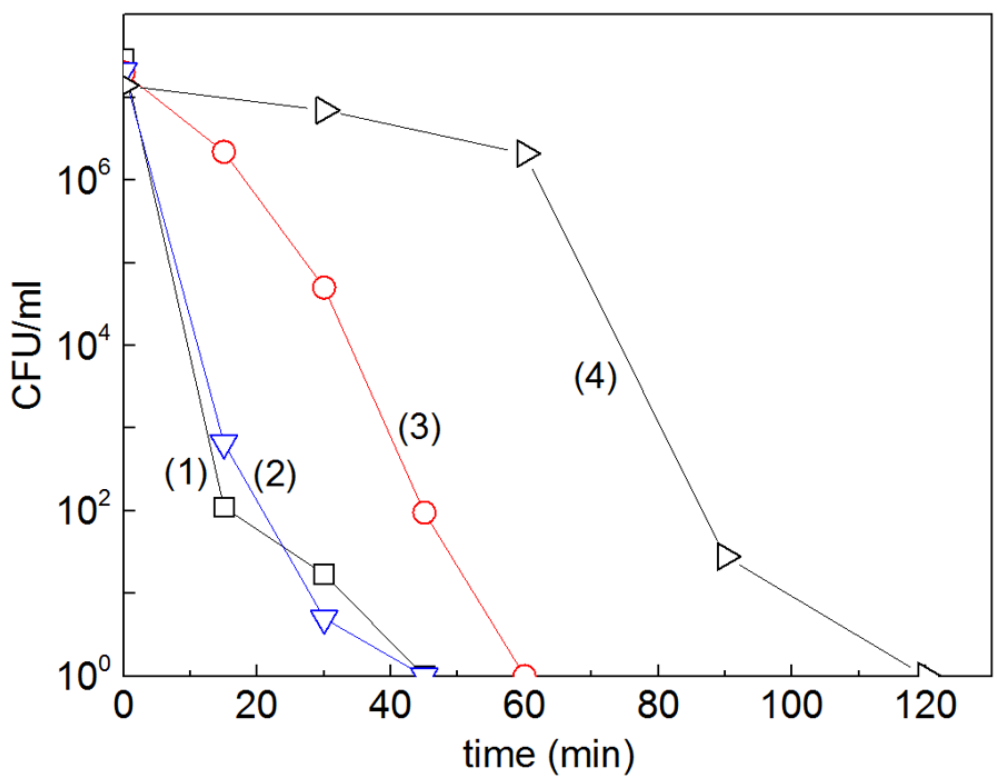

Figure 5. E. coli inactivation by $\mathrm{TiO}_{2}-\mathrm{ZrO}_{2} / \mathrm{Cu}$ sputtered for $8 \mathrm{~min} / 10 \mathrm{~s}$ under Suntest simulated solar light at three different light intensities as shown by traces: (1) $70 \mathrm{~mW} / \mathrm{cm}^{2}$ (2) $50 \mathrm{~mW} / \mathrm{cm}^{2}$ and (3) $30 \mathrm{~mW} / \mathrm{cm}^{2}$. For comparison purposes, trace (4) shows the bacterial inactivation on $\mathrm{TiO}_{2}-\mathrm{ZrO}_{2}$.
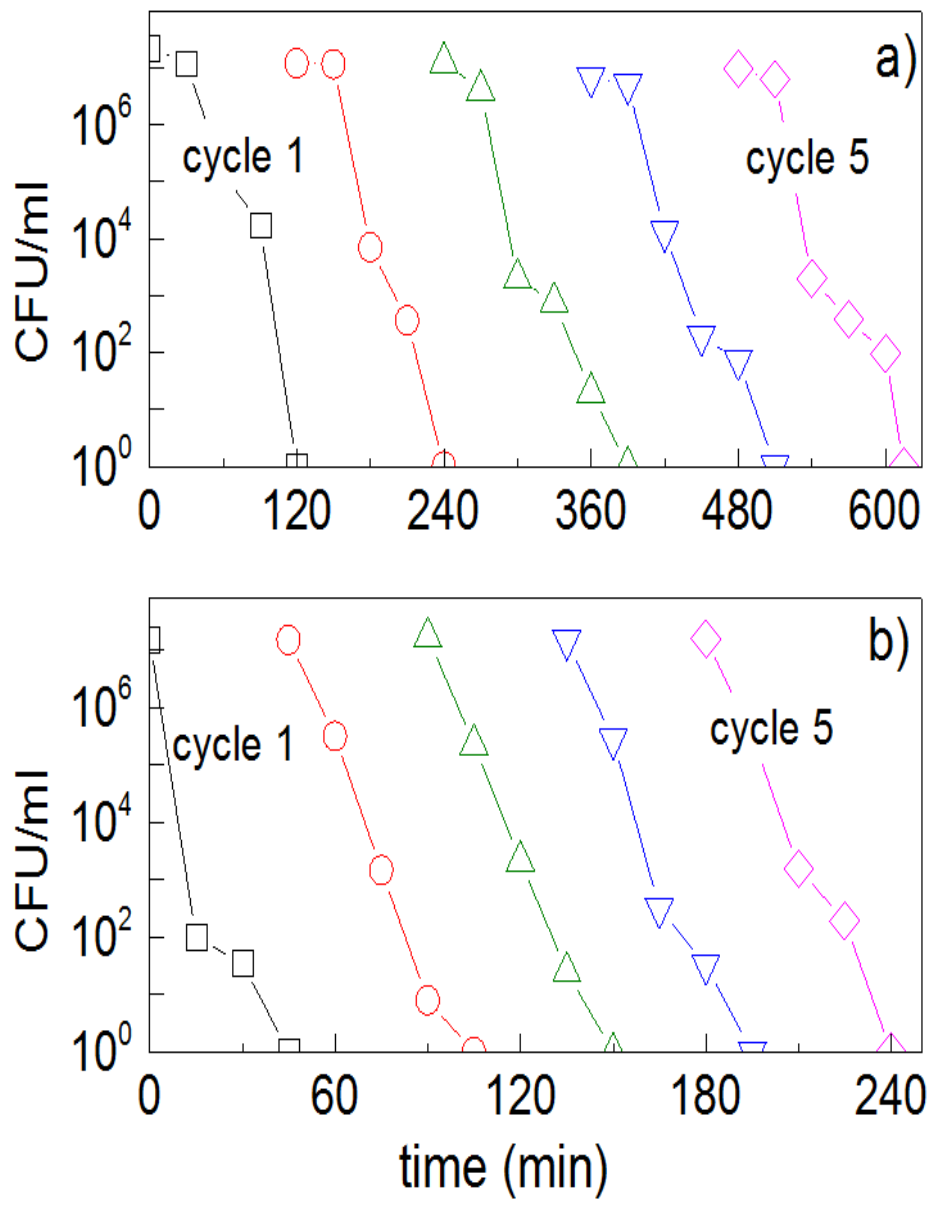

Figure 6. Recycling of $\mathrm{TiO}_{2}-\mathrm{ZrO}_{2}(8 \mathrm{~min})$ and $\mathrm{TiO}_{2}-\mathrm{ZrO}_{2} / \mathrm{Cu}(8 \mathrm{~min} / 10 \mathrm{~s})$ under low intensity solar simulated light $\left(50 \mathrm{~mW} / \mathrm{cm}^{2}\right)$. 

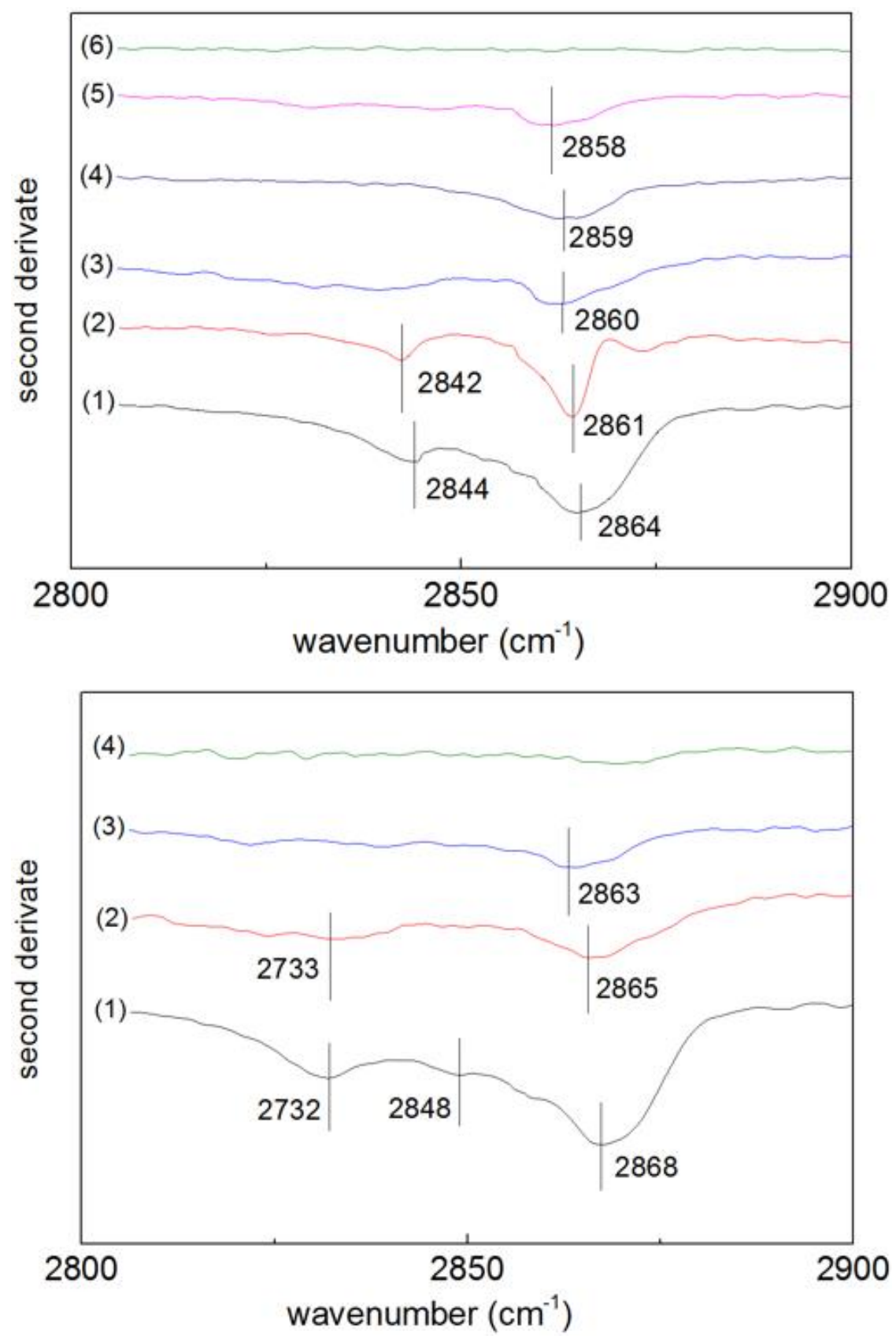

Figure 7a. Shift in the $-\mathrm{CH}_{2}$ vibrational peaks and amplitude changes during the bacterial inactivation of $E$. coli under light irradiation $\left(50 \mathrm{~mW} / \mathrm{cm}^{2}\right)$ followed by FTIR on $\mathrm{TiO}_{2}-\mathrm{ZrO}_{2}$ on PES at: (1) time zero, (2) after $15 \mathrm{~min},(3)$ after $30 \mathrm{~min},(4)$ after $60 \mathrm{~min},(5)$ after $90 \mathrm{~min}$ and (6) after $120 \mathrm{~min}$.

Figure $7 \mathrm{~b}$. Shift in the $-\mathrm{CH}_{2}$ vibrational peaks and amplitude changes during the bacterial inactivation of $E$. coli under light irradiation $\left(50 \mathrm{~mW} / \mathrm{cm}^{2}\right)$ followed by FTIR on $\mathrm{TiO}_{2}-\mathrm{ZrO}_{2}-\mathrm{Cu}$ on PES at: (1) time zero, (2) after $15 \mathrm{~min}$, (3) after $30 \mathrm{~min}$, (4) after $45 \mathrm{~min}$, 


\section{Graphical Abstract:}

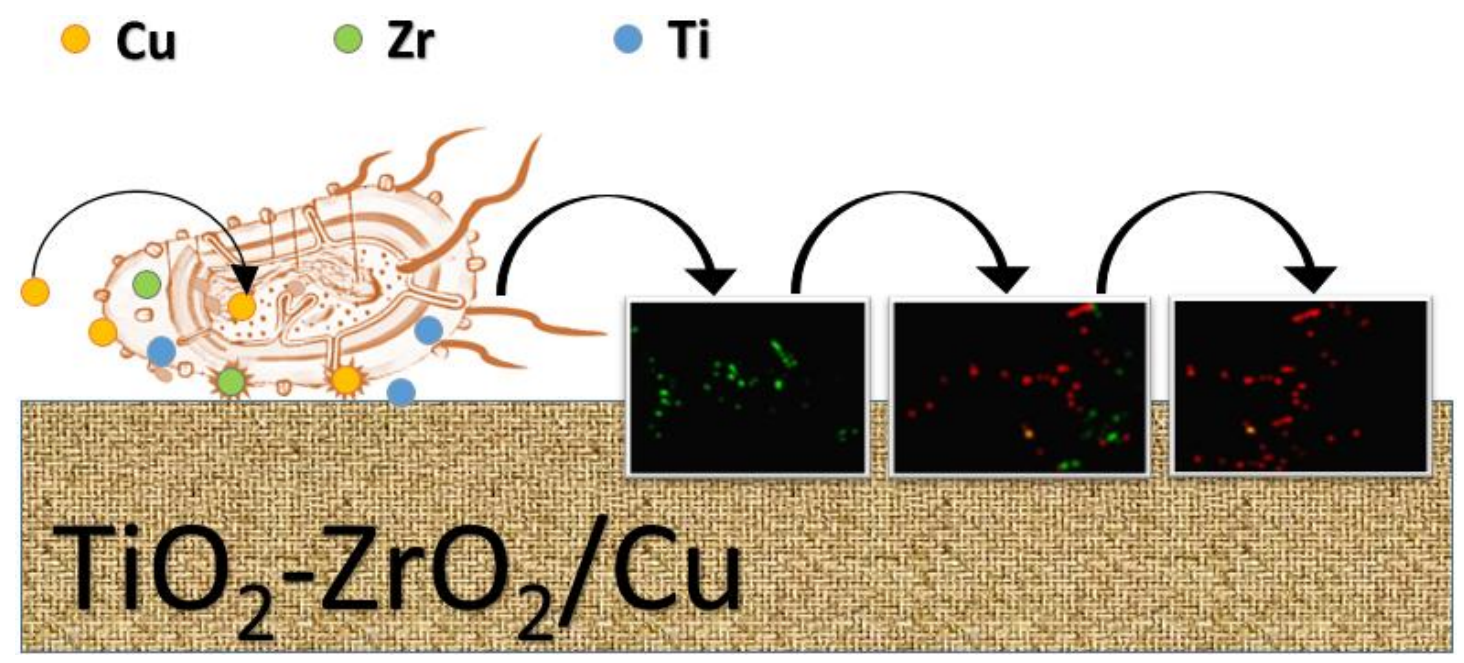

The photo-generated ROS and $\mathrm{Cu} / \mathrm{Cu}$-ions damage the E. coli cell envelope and subsequently enter the cytoplasm leading to cell killing. 